\title{
NMR resonance assignments of the four isoforms of the hazelnut allergen Cor a 1.04
}

\author{
Sebastian Führer ${ }^{1}(\mathbb{D}) \cdot$ Ricarda Zeindl $^{1}\left[\right.$ Martin $^{-}$Tollinger $^{1}(\mathbb{C}$
}

Received: 26 September 2019 / Accepted: 1 November 2019 / Published online: 5 November 2019

(c) The Author(s) 2019

\begin{abstract}
In large parts of Europe, Northern America and China people are suffering from allergies after consuming certain kinds of fruits and vegetables. Typical allergic symptoms range from scratching and itching of the throat to severe symptoms like rhino conjunctivitis and anaphylaxis. For hazelnuts (Corylus avellana), these allergies result from initial sensitization to the birch (Betula verrucosa) pollen allergen Bet $\mathrm{v} 1$ and subsequent development of allergic cross-reactions to proteins that are similar in their three-dimensional structure to the sensitizing protein Bet $\mathrm{v} 1$. The cross-reactive proteins in hazelnut are the four isoforms Cor a 1.04 with a molecular weight of about $17.5 \mathrm{kDa}$. Significant differences regarding the immunologic behavior of these proteins have been reported. In this work we assigned backbone and side chain ${ }^{1} \mathrm{H},{ }^{13} \mathrm{C}$, and ${ }^{15} \mathrm{~N}$ chemical shifts of these four isoforms, Cor a 1.0401, Cor a 1.0402, Cor a 1.0403, and Cor a 1.0404 by solution NMR spectroscopy. The chemical shift data confirm the characteristic Bet $\mathrm{v}$ onefold for all four isoforms, consisting of seven $\beta$-strands that are separated by two short $\alpha$-helices, along with a long C-terminal $\alpha$-helix. These data provide the basis for a comparative structural and dynamic analysis of these proteins by NMR in order to characterize their different immunologic cross-reactivities on a molecular level.
\end{abstract}

Keywords NMR resonance assignment $\cdot$ TALOS + prediction $\cdot$ PR-10 protein $\cdot$ Cross-reactivity $\cdot$ Allergen

\section{Biological context}

In the northern hemisphere, pollinosis caused by sensitization to birch pollen is the most common allergy. In 62-98\% of birch pollen allergic patients IgE-specific antibodies are directed at the protein Bet $\mathrm{v}$ 1, the major birch pollen allergen (Ipsen and Lowenstein 1983; Moverare et al. 2002). Immunological cross-reactivity of Bet $v 1$ specific antibodies (IgE) to proteins that are present in fruits and nuts can provoke additional allergic reactions in patients suffering from birch pollinosis. These foods typically trigger oral allergic syndromes (OAS), including itching and scratching of the oral cavity, directly after consumption (Mari et al. 2005). Allergic reactions to raw hazelnuts are among the most prevalent manifestations of these birch pollen related food allergies, affecting $60-70 \%$ of all individuals, who are

Martin Tollinger

martin.tollinger@uibk.ac.at

1 Institute of Organic Chemistry, Center for Molecular Biosciences Innsbruck (CMBI), University of Innsbruck, Innrain 80/82, 6020 Innsbruck, Austria sensitized towards birch pollen (Geroldinger-Simic et al. 2011; Hansen et al. 2009).

Allergic cross-reactivities are associated with the class 10 of pathogenesis related (PR) proteins in hazelnut and hazel pollen (Vieths et al. 2002), whose expression is induced by environmental or pathogenic stress. These allergens consist of about 160 amino acid residues with a molecular weight of $\sim 17.5 \mathrm{kDa}$. The canonical fold of PR-10 proteins comprises seven antiparallel $\beta$-strands $(\beta 1-\beta 7)$, which are interrupted by two short $\alpha$-helices ( $\alpha 1$ and $\alpha 2)$ between strands $\beta 1$ and $\beta 2$. In addition, the $\beta$-sheet is covered by a long C-terminal $\alpha$-helix (Fernandes et al. 2013). It was shown that allergic cross-reactions decrease after roasting of the hazelnuts, which indicates the general heat lability of these proteins (Verhoeckx et al. 2015). The PR-10 proteins found in hazel pollen are grouped into the Cor a 1.01 isoforms (Breiteneder et al. 1993), while Cor a 1.04 isoforms are found in the hazelnut. Four Cor a 1.04 isoforms have been identified (Hirschwehr et al. 1992) and their IgEbinding capacity was studied in detail (Lüttkopf et al. 2002). These isoforms are Cor a 1.0401 (AF136945), Cor a 1.0402 (AF323973), Cor a 1.0403 (AF323974), and Cor a 1.0404 


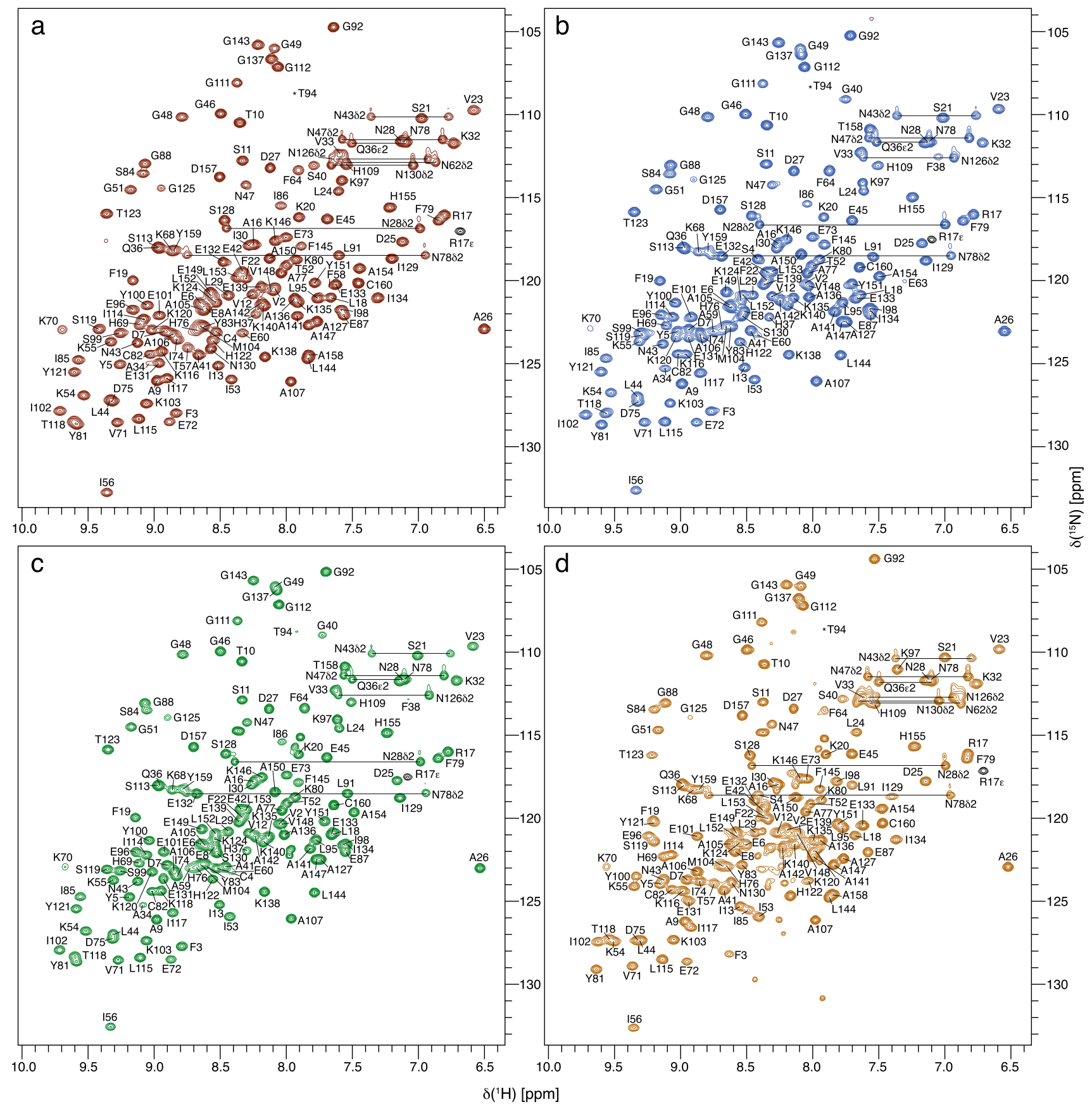

Fig. $1500 \mathrm{MHz}{ }^{1} \mathrm{H}^{15}{ }^{15} \mathrm{~N}-\mathrm{HSQC}$ spectrum of a Cor a 1.0401 , b Cor a 1.0402, c Cor a 1.0403, and d Cor a 1.0404 (each $0.5 \mathrm{mM}$ ) in $20 \mathrm{mM}$ sodium phosphate (pH 6.9) and $2 \mathrm{mM}$ DTT, supplemented with $10 \% \mathrm{D}_{2} \mathrm{O}$ at $25{ }^{\circ} \mathrm{C}$. Assigned residues are indicated by single letter codes and horizontal lines indicate asparagine and glutamine $\mathrm{NH}_{2}$

(AF323975) (Hirschwehr et al. 1992), which share a sequence identity of about $97 \%$ among each other, and only about 63 and $66 \%$ to the pollen allergens Cor a 1.01 and Bet v 1.0101 (Gajhede et al. 1996), respectively. The PR-10 food allergens from apple (Malus domestica) Mal d 1.0101 (Ahammer et al. 2017, 2016) and peach (Prunus Opersica) side-chain resonances. The signals labeled by an asterisk indicates the positions of residues below the intensity cut-off. Resonance assignments are available online at the BMRB repository (Accession numbers for Cor a 1.0401, Cor a 1.0402, Cor a 1.0403, and Cor a 1.0404 are $27,965,27,961,27,967$, and 28,016 , respectively)

Pru p 1.0101 (Führer et al. 2019), which show the highest birch pollen associated food hypersensitivity along with Cor a 1.04 , have sequence identities of $62-64 \%$ to the four Cor a 1.04 isoforms. Using an enzyme allergosorbent test, it was shown that the various Cor a 1.04 proteins significantly differ with respect to their IgE-reactivity, resulting 
in the immunological ranking Cor a $1.0401>02>03>04$ (Lüttkopf et al. 2002). In this work we present the solution NMR backbone and side-chain assignments of the four recombinantly expressed isoforms of Cor a 1.04.

\section{Methods and experiments}

\section{Sample preparation}

Transformation of the codon-optimized plasmids of Cor a 1.0401 (GenBank nucleotide code AF136945 and protein code AAD48405), Cor a 1.0402 (GenBank nucleotide code AF323973 and protein code AAG40329), Cor a 1.0403 (GenBank nucleotide code AF323974 and protein code AAG40330), and Cor a 1.0404 (GenBank nucleotide code AF323975 and protein code AAG40331), which were cloned in the expression vector pET28b (+) using restriction enzymes NcoI and XhoI, was conducted in the E. coli strain BL21(DE3) Star (Invitrogen). An overnight culture (100 mL) of Luria-Bertani (LB) medium with $25 \mu \mathrm{g} / \mathrm{mL}$ kanamycin was inoculated with one bacterial colony and incubated overnight at $37^{\circ} \mathrm{C}$ and $200 \mathrm{rpm}$. The volume of the overnight culture, which was centrifuged at $2000 \times g$, to reach a cell density of 0.1 in the final expression culture, was calculated by $\mathrm{V}_{\mathrm{o} / \mathrm{n}}=\left(0.1 \times \mathrm{V}_{\text {expression }}\right) / \mathrm{A}_{600, \mathrm{o} / \mathrm{n}}$. The cell pellet was resuspended in $1 \mathrm{~L}$ of $\mathrm{M} 9$ minimal medium enriched with $1 \mathrm{~g} / \mathrm{L}$ ${ }^{15} \mathrm{NH}_{4} \mathrm{Cl}$ or $3 \mathrm{~g} / \mathrm{L}{ }^{13} \mathrm{C}_{6}$-D-glucose and $1 \mathrm{~g} / \mathrm{L}{ }^{15} \mathrm{NH}_{4} \mathrm{Cl}$ (both Cambridge Isotope Laboratories) and supplemented with $25 \mu \mathrm{g} / \mathrm{mL}$ kanamycin. Additionally, $1 \mathrm{~g} / \mathrm{L}$ ISOGRO ${ }^{\circledR} \_{ }^{15} \mathrm{~N}$ or $1 \mathrm{~g} / \mathrm{L}$ ISOGRO ${ }^{\circledR}-{ }^{13} \mathrm{C},{ }^{15} \mathrm{~N}$ powder (both Sigma-Aldrich) was added to the medium. The culture was incubated at $37^{\circ} \mathrm{C}$ and $200 \mathrm{rpm}$ until the cell density reached $0.5-0.6$ (at $600 \mathrm{~nm}$ ), subsequently protein expression was induced by addition of isopropyl- $\beta$-D-1-thiogalactopyranosid (IPTG, $1 \mathrm{mM}$ ) and performed for $3 \mathrm{~h}$ at $37^{\circ} \mathrm{C}$. Cells were harvested at $3440 \times g$ and $4{ }^{\circ} \mathrm{C}$ for $35 \mathrm{~min}$, resuspended in a buffer containing $25 \mathrm{mM}$ imidazole, $0.1 \%$ Triton X-100, and $0.5 \mathrm{M}$ urea, shock-frozen in liquid nitrogen and stored at $-80{ }^{\circ} \mathrm{C}$ until usage. Lysate preparation was done by thawing the cells and pre-treating for $1 \mathrm{~h}$ on ice with lysozyme $(10 \mu \mathrm{g} / \mathrm{mL})$ and only for Cor a 1.0404 additionally with $300 \mu \mathrm{l}$ protease inhibitor cocktail His-tag (Carl Roth) per $50 \mathrm{~mL}$ suspension. Afterwards, DNAse $(1 \mu \mathrm{g} / \mathrm{mL})$ was added and the cells were passed through a French Press and centrifuged at $15,000 \times g$ and $4{ }^{\circ} \mathrm{C}$ for $35 \mathrm{~min}$. The cleared lysate was loaded onto an anion exchange column (Resource Q $6 \mathrm{~mL}$, GE Healthcare) and the desired Cor a 1.04 proteins were eluted with a sodium chloride gradient over $30 \mathrm{~mL}$ from 0 to $50 \%$ in $25 \mathrm{mM}$ TrisHCl buffer ( $\mathrm{pH} 7.5$ ) at a flow rate of $2 \mathrm{~mL} / \mathrm{min}$. Cor a 1.04 containing fractions were collected and concentrated to about $1.5 \mathrm{~mL}$ by centrifugation (Amicon Ultra $3 \mathrm{kDa}$ MWCO, Merck Millipore). For the final purification step the corresponding
Table 1 Completeness of backbone and side-chain resonance assignments for the four different isoforms of Cor a 1.04

\begin{tabular}{lllll}
\hline & $\begin{array}{l}\text { Cor a } \\
1.0401(\%)\end{array}$ & Cor a 1.0402(\%) & $\begin{array}{l}\text { Cor a } \\
1.0403(\%)\end{array}$ & $\begin{array}{l}\text { Cor a } \\
1.0404 \\
(\%)\end{array}$ \\
\hline $\mathrm{C}^{\prime}$ & 94.4 & 95.0 & 94.4 & 90.0 \\
$\mathrm{C}^{\alpha}$ & 95.0 & 95.6 & 94.4 & 90.6 \\
$\mathrm{C}^{\beta}$ & 97.2 & 95.8 & 95.1 & 92.4 \\
$\mathrm{C}^{\gamma}$ & 72.6 & 70.1 & 71.6 & 68.4 \\
$\mathrm{C}^{\delta}$ & 78.8 & 75.8 & 76.8 & 72.0 \\
$\mathrm{C}^{\varepsilon}$ & 71.4 & 69.0 & 76.2 & 61.9 \\
$\mathrm{H}$ & 91.4 & 92.1 & 91.4 & 88.0 \\
$\mathrm{H}^{\alpha}$ & 92.6 & 92.1 & 91.5 & 86.9 \\
$\mathrm{H}^{\beta}$ & 93.1 & 91.8 & 92.2 & 87.8 \\
$\mathrm{H}^{\gamma}$ & 88.8 & 85.7 & 90.1 & 79.0 \\
$\mathrm{H}^{\delta}$ & 93.4 & 88.1 & 92.4 & 85.5 \\
$\mathrm{H}^{\varepsilon}$ & 69.4 & 72.6 & 74.2 & 64.5 \\
$\mathrm{~N}$ & 90.8 & 91.4 & 90.8 & 87.4 \\
$\mathrm{~N}^{\delta}$ & 85.7 & 83.3 & 83.3 & 85.7 \\
$\mathrm{~N}^{\varepsilon}$ & 77.8 & 77.8 & 77.8 & 77.8 \\
\hline
\end{tabular}

Assignment for the backbone amide corresponds to non-proline residues

protein was loaded onto a size exclusion column (HiLoad 16/600 Superdex 75 prep grade, GE Healthcare) and eluted isocratically at $1 \mathrm{~mL} / \mathrm{min}$ with a $10 \mathrm{mM}$ sodium phosphate buffer (pH 6.9) containing $2 \mathrm{mM}$ DTT. All purification steps were monitored by SDS-PAGE gel electrophoresis with $15 \%$ gels. Samples were supplemented with $10 \% \mathrm{D}_{2} \mathrm{O}(\mathrm{v} / \mathrm{v})$ for NMR spectroscopy, yielding concentrations of $0.5 \mathrm{mM}$ for ${ }^{15} \mathrm{~N}$ labeled and ${ }^{15} \mathrm{~N} /{ }^{13} \mathrm{C}$ labeled Cor a 1.04 proteins.

\section{NMR spectroscopy}

A $500 \mathrm{MHz}$ Agilent DirectDrive 2 spectrometer equipped with a room temperature probe was used to record all NMR spectra at $25^{\circ} \mathrm{C}$. Backbone resonance assignments were performed using a two-dimensional ${ }^{1} \mathrm{H}_{-}{ }^{15} \mathrm{~N}-\mathrm{HSQC}$ and three-dimensional HNCACB, CBCA $(\mathrm{CO}) \mathrm{NH}, \mathrm{HNCO}$, and $\mathrm{HN}(\mathrm{CA}) \mathrm{CO}$ experiments. A two-dimensional ${ }^{1} \mathrm{H}_{-}{ }^{13} \mathrm{C}-\mathrm{HSQC}$ and three-dimensional $(\mathrm{H}) \mathrm{CC}(\mathrm{CO}) \mathrm{NH}-\mathrm{TOCSY}, \mathrm{H}(\mathrm{CCO})$ NH-TOCSY, ${ }^{1} \mathrm{H}_{-}{ }^{15} \mathrm{~N}-\mathrm{TOCSY}$-HSQC,${ }^{1} \mathrm{H}_{-}{ }^{15} \mathrm{~N}$-NOESYHSQC, and ${ }^{1} \mathrm{H}_{-}{ }^{13} \mathrm{C}-\mathrm{NOESY}-\mathrm{HSQC}$ experiments were used to perform side-chain assignments. Assignment of the aromatic side-chains of phenylalanines, tyrosines and histidines was obtained from aromatic ${ }^{1} \mathrm{H}_{-}^{13} \mathrm{C}$-HSQC experiments, a three-dimensional aromatic ${ }^{1} \mathrm{H}^{1}{ }^{13} \mathrm{C}$-NOESY-HSQC experiment and a ${ }^{1} \mathrm{H}^{-15} \mathrm{~N}-\mathrm{HSQC}$ experiment with coherence transfer optimized for ${ }^{2} J$ couplings in imidazole side-chains of histidines. Data processing was performed with NMRPipe (Delaglio et al. 1995) and the CcpNMR software package was used for resonance assignment (Vranken et al. 2005). 

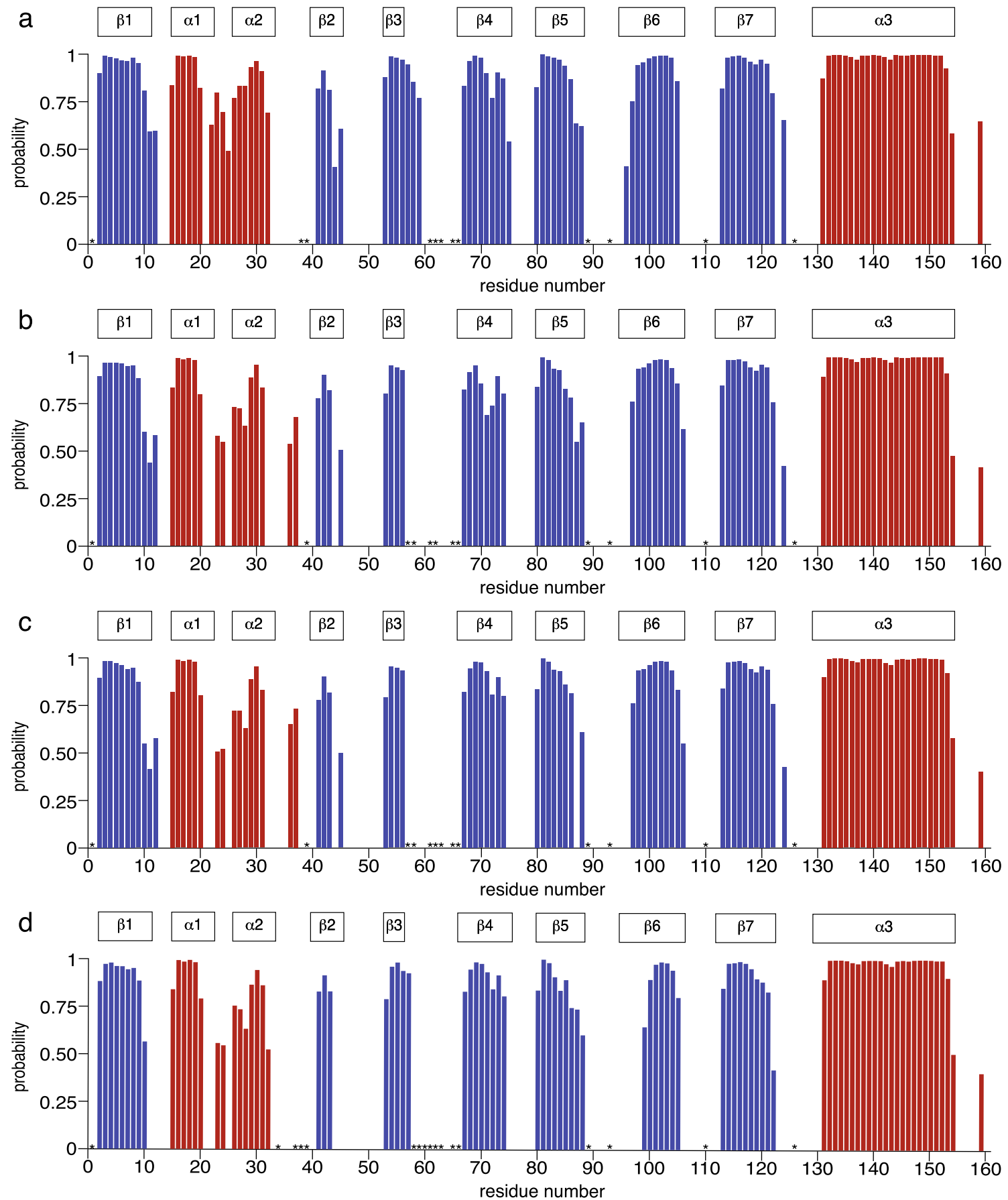

Fig. 2 Secondary structure of a Cor a 1.0401, b Cor a 1.0402, c Cor a 1.0403 , and $\mathbf{d}$ Cor a 1.0404 as predicted by TALOS + , based on backbone $\mathrm{H}^{\mathrm{N}}, \mathrm{N}, \mathrm{C}^{\prime}, \mathrm{C}^{\alpha}$, and $\mathrm{C}^{\beta}$ chemical shifts. Secondary structure probabilities (red, $\alpha$-helices; blue, $\beta$-strands) are plotted versus

\section{Assignments and data deposition}

We were able to assign 138 of 152 non-proline residues for Cor a 1.0401 (Fig. 1a), 139 of 152 non-proline residues for Cor a 1.0402 (Fig. 1b), 138 of 152 non-proline residues for Cor a 1.0403 (Fig. 1c), and 132 of 151 non-proline residues residue numbers. Asterisks indicate residues for which backbone amide NH resonance assignments are not available. Secondary structure elements of Bet v 1.0101 (PDB: 4A88) are indicated on top

for Cor a 1.0404 (Fig. 1d). The ${ }^{1} \mathrm{H}^{15}{ }^{15} \mathrm{~N}-\mathrm{HSQC}$ spectra of Cor a 1.0401-03 show well folded proteins with very similar shift distributions, in agreement with their high sequence identities. The spectrum of the least allergenic isoform Cor a 1.0404 shows additional peaks in ${ }^{1} \mathrm{H}-{ }^{15} \mathrm{~N}-\mathrm{HSQC}$ spectra, 
which probably arise from partial protein unfolding or degradation despite the use of protease inhibitors (Table 1).

The accession numbers at the Biological Magnetic Resonance Data Bank (http://www.bmrb.wisc.edu) for Cor a 1.0401, Cor a 1.0402, Cor a 1.0403, and Cor a 1.0404 are $27,965,27,961,27,967$, and 28,016, respectively. Based on the $\mathrm{H}^{\mathrm{N}}, \mathrm{N}, \mathrm{C}^{\prime}, \mathrm{C}^{\alpha}$, and $\mathrm{C}^{\beta}$ backbone chemical shifts, the TALOS + software (Shen et al. 2009) was used to predict the secondary structure elements of the four Cor a 1.04 isoforms (Fig. 2). These data are in agreement with the PR-10 fold, containing seven Q-strands $(\beta 1-\beta 7)$ that are interrupted by two short $\alpha$-helices $(\alpha 1$ and $\alpha 2)$ and a long C-terminal $\alpha$-helix. An additional propensity for $\alpha$-helical structure is found for the segment between $\alpha 2$ and $\beta 2$ in two isoforms, while a moderate $\alpha$-helical propensity is also present after the $\mathrm{C}$-terminal helix in all four proteins. In some loop regions, particularly between $\alpha 2 / \beta 2, \beta 3 / \beta 4$, and $\beta 5 / \beta 6$, several resonances are absent in ${ }^{1} \mathrm{H}-{ }^{15} \mathrm{~N}-\mathrm{HSQC}$ and triple-resonance spectra of all four isoforms, possibly due to conformational exchange or due to exchange of backbone amides with solvent.

The NMR resonance assignment of Cor a 1.0401, Cor a 1.0402 , Cor a 1.0403, and Cor a 1.0404 obtained in this work will enable us to analyze structural and dynamic properties of these proteins in detail in a comparative manner, and to relate these properties to the previously observed differences in their immunological reactivities.

Acknowledgements Open Access funding was provided by the Austrian Science Fund (FWF). This work was supported by the Austrian Science Fund FWF (P26849) and the Austrian Research Promotion Agency FFG (project 858017, West-Austrian BioNMR). We thank Dr. Kathrin Breuker, Dr. Thomas Müller, and Christina Meisenbichler for mass spectrometry experiments.

Open Access This article is distributed under the terms of the Creative Commons Attribution 4.0 International License (http://creativeco mmons.org/licenses/by/4.0/), which permits unrestricted use, distribution, and reproduction in any medium, provided you give appropriate credit to the original author(s) and the source, provide a link to the Creative Commons license, and indicate if changes were made.

\section{References}

Ahammer L, Grutsch S, Tollinger M (2016) NMR resonance assignments of the major apple allergen Mal d 1. Biomol NMR Assign 10:287-290. https://doi.org/10.1007/s12104-016-9685-8

Ahammer L, Grutsch S, Kamenik AS, Liedl KR, Tollinger M (2017) Structure of the major apple allergen Mal d 1. J Agric Food Chem 65:1606-1612. https://doi.org/10.1021/acs.jafc.6b05752

Breiteneder H et al (1993) Four recombinant isoforms of Cor a I, the major allergen of hazel pollen, show different
IgE-binding properties. Eur J Biochem 212:355-362. https://doi. org/10.1111/j.1432-1033.1993.tb17669.x

Delaglio F, Grzesiek S, Vuister GW, Zhu G, Pfeifer J, Bax A (1995) NMRPipe: a multidimensional spectral processing system based on UNIX pipes. J Biomol NMR 6:277-293. https://doi. org/10.1007/BF00197809

Fernandes H, Michalska K, Sikorski M, Jaskolski M (2013) Structural and functional aspects of PR-10 proteins. FEBS J 280:1169-1199. https://doi.org/10.1111/febs.12114

Führer S, Trimmel S, Breuker K, Tollinger M (2019) NMR resonance assignments of the pathogenesis-related peach allergen Pru p 1.0101. Biomol NMR Assign 13:127-130. https://doi. org/10.1007/s12104-018-9864-x

Gajhede M et al (1996) X-ray and NMR structure of Bet v 1, the origin of birch pollen allergy. Nat Struct Biol 3:1040-1045

Geroldinger-Simic M et al (2011) Birch pollen-related food allergy: clinical aspects and the role of allergen-specific IgE and $\mathrm{IgG} 4$ antibodies. J Allergy Clin Immunol 127(616-622):e611. https:// doi.org/10.1016/j.jaci.2010.10.027

Hansen KS et al (2009) Component-resolved in vitro diagnosis of hazelnut allergy in Europe. J Allergy Clin Immun 123:1134-1141. https://doi.org/10.1016/j.jaci.2009.02.005

Hirschwehr R et al (1992) Identification of common allergenic structures in hazel pollen and hazelnuts: a possible explanation for sensitivity to hazelnuts in patients allergic to tree pollen. $\mathbf{J}$ Allergy Clin Immunol 90:927-936. https://doi.org/10.1016/00916749(92)90465-e

Ipsen H, Lowenstein H (1983) Isolation and immunochemical characterization of the major allergen of birch pollen (Betula verrucosa). J Allergy Clin Immunol 72:150-159

Lüttkopf D et al (2002) Comparison of four variants of a major allergen in hazelnut (Corylus avellana) Cor a 1.04 with the major hazel pollen allergen Cor a 1.01. Mol Immunol 38:515-525

Mari A, Ballmer-Weber BK, Vieths S (2005) The oral allergy syndrome: improved diagnostic and treatment methods. Curr Opin Allergy Clin Immunol 5:267-273

Moverare R et al (2002) Different IgE reactivity profiles in birch pollen-sensitive patients from six European populations revealed by recombinant allergens: an imprint of local sensitization. Int Arch Allergy Immunol 128:325-335

Shen Y, Delaglio F, Cornilescu G, Bax A (2009) TALOS + : a hybrid method for predicting protein backbone torsion angles from NMR chemical shifts. J Biomol NMR 44:213-223. https://doi. org/10.1007/s10858-009-9333-Z

Verhoeckx KCM et al (2015) Food processing and allergenicity. Food Chem Toxicol 80:223-240. https://doi.org/10.1016/j. fct.2015.03.005

Vieths S, Scheurer S, Ballmer-Weber B (2002) Current understanding of cross-reactivity of food allergens and pollen. Ann N Y Acad Sci 964:47-68

Vranken WF et al (2005) The CCPN data model for NMR spectroscopy: development of a software pipeline. Proteins 59:687-696. https://doi.org/10.1002/prot.20449

Publisher's Note Springer Nature remains neutral with regard to jurisdictional claims in published maps and institutional affiliations. 